\title{
NARRATIVE GAME CONSTRUING OF ENGLISH FAIRY NARRATIVES
}

\section{Tsapiv A. O.}

\section{INTRODUCTUION}

In the past few decades, children's literature has become a field of academic study in its own right. Academics analyze literary texts for children for both general and academic readership ${ }^{1}$. Much of these researches started in 1960s in most English-speaking countries. Scholars focused their attention on exploring the history of the development of children's literature, its most popular genres (fairy tales, fantasy novels), topics and styles which came into vogue at different times ${ }^{2}$.

Presently, many academic researches are dedicated to revealing cultural specificity of literary texts for children. How is it realized in the text? What makes literary texts for children of various linguistic cultures be different ${ }^{3}$.

Narrative is a complex unit structure which unfolds into two basic components: narrative and narration ${ }^{4}$. We assume that narrative is a story about sequence of events syntagmatically or paradigmatically built. Narration refers to the process of constructing these events via verbal and/or nonverbal medium ${ }^{5}$. Narration is the process of creating a fictional world with human or anthropomorphic characters who exist in fictional time and space and perform goal-directed actions ${ }^{6}$. In literary texts where verbal (sometimes visual) medium dominates, the text world is represented by a narrator, who functions as a mediator ${ }^{7}$. A narrator shapes a story

${ }^{1}$ Hahn D. The Oxford companion to Children's literature. Oxford University press, 2017. P. 123-124.

${ }^{2}$ Hunt P. Understanding Children's literature. London and New York : Routledge Taylor and Francis Group, 2005. 225 p.

${ }^{3}$ Hunt P. Understanding Children's literature. London and New York : Routledge Taylor and Francis Group, 2005. P. 50-72; Nikolajeva M. Children's literature comes of age. London and New York: Rouledge Taylor \& Frances Group, 2016. 225 p.

${ }_{5}^{4}$ Женетт Жерар Фигуры . М.: изд-во им. Сабашниковых, 1998. 944 с.

5 Chatman S. Story and discourse. Narrative structure in fiction and film. Ithaca and London: Cornell University Press, 1980. P. 22.

${ }^{6}$ Fludernik M. An introduction to narratology. London and New York: Rouledge. Taylor and Francis group, 2002. P. 4-10.

${ }^{7}$ Margolin, U. Narrator. Handbook of narratology. Berlin / New York : Walter de Gruyter, 2009. P. $351-365$ 
(narrative) by choosing all the building elements for it: focalization, narrative episodes, gives or does not give access to character's thoughts and plans.

This article presents the narratological analysis of the fairy narratives "Charlie and the Chocolate Factory" and "Charlie and the Great Glass Elevator" proposed to account for the ways in which fairy tale text processing is understood and the methodology of its research is elaborated (it helps working out the algorithm of a fairy tale analysis and the methodology of research as a whole). The methodology of investigation has underpinnings in the theory of narrative (M. Bal, S. Chatman, M.Fludernik, W. Shmid, $)^{8}$, in the basic assumptions of the text world theory (M. Ryan, G. Gavens, E. Semino) ${ }^{9}$ and E. Semino's schema theory, reasoning and re-conceptualization of V. Propp's morphology of fairy tales and poetics of folklore (see his seminal work "Morphology of Folktale" and commentaries of Levi Strauss) ${ }^{10}$ as well as findings in contemporary cognitive science and pragmatics. It also has underpinning in the theory of Russian Formalists related to the notions of defamiliarization and impeded forms (V. Shklovsky $)^{11}$, and in the assumptions of cognitive poetics concerning modification of cognitive processes for creating specific poetic effects (R. Tsur) ${ }^{12}$ as well as in cognitive metaphor and schema theory ${ }^{13}$. The paper suggests top-down and bottom-up analyses of the semantics of literary texts aimed at exposing its specific stylistic means and cognitive operations in creating poetics of narrative, evaluating communicative and pragmatic effects of such poetics on the child-reader.

Case study of the research are Roald Dahl's fairy narratives "Charlie and the Chocolate Factory" and "Charlie and the great glass elevator".

\footnotetext{
${ }^{8}$ Bal M. Narratology. Introduction to the theory of narrative. Toronto. Buffalo. London : University of Toronto Press, 2017. 205 p.; Chatman S. Story and discourse. Narrative structure in fiction and film. Ithaca and London: Cornell University Press, 1980. 277 p.; Fludernik M. An introduction to narratology. London and New York: Rouledge. Taylor and Francis group, 2002.190 р.; Шмид В. Нарратология. М. : Языки славянской культуры, 2003. $312 \mathrm{c}$.

9 Ryan Marie-Laure Possible Worlds, Artificial Intelligence and Narrative Theory. Bloomington: Indiana University Press, 1991. 304 p.; Semino E. Text worlds. Cognitive poetics: Goals, Gains and Gaps. Berlin. New York : Mouton de Gruyter, 2009. P. 33-73; 1. J. Gavins Text world theory. An introduction. Edinburgh University Press, 2007. 103 p.

${ }^{10}$ Пропп В. Морфология сказки. Ленинград: «Аcademia», 1928. 152 с.

11 Shklovsky V. Theory of Prose. Dalkey archives press, 1991. 240 p.

12 Tsur R. Metaphor and figure-ground relationship: comparisons from poetry, music, and the visual arts. Cognitive poetics: goals, gains and gaps. Berlin. New York : Mouton de Gruyter, 2009. P. 237-279.

${ }^{13}$ Lakoff, G., Turner, M. More than cool reason: a field guide to poetic metaphor . The University of Chicago Press. Chicago and London, 1989. 237 p.
} 


\section{Game nature of fairy narratives}

Narratives are stories about some events told by a narrator to a narratee. Fiction narrative presupposes construing the narrative by means of special literary language. Literary texts for children have some peculiar features that make them different from the literature, intentionally addressed to adult readers. Writers are well aware of the potential realization of the text by its implied reader, especially in regard to the following aspects (which, of course, are mutually dependent): the text's complexity, the structure of the narration, the stylistic level, and the subject matter $^{14}$.

There have been lots of researches aimed at revealing factors, both extralinguistic and linguistic, which give answers to the question: What makes this text be a literary text for children? I would claim, that a number of scientific papers really unveil the specificity of fiction narratives for children, though, most of them still focus on extralinguistic parameters. Most these researches concentrate on didactic function of such texts, their psychological and pedagogical aspect, ability to influence a child's understanding of Good and Evil (see researches of J. Zipes) ${ }^{15}$.

Narratology is a multidisciplinary science, which provides scholars with various tools for interpreting the text and its wide context. Narratological analysis embraces methods of psycholinguistics, cognitive linguistics (fictional minds, character's inner world), cultural studies (cultural specificity, inherent in the text), literature studies (text types, genre studies), different types of linguistic analysis, such as stylistic (expressive means and stylistic devices), syntactical (types of syntactic structures), semantic (narrative triggers), analysis of text's composition structure (linear or non-linear) ${ }^{16}$.

As any linguistic paradigm, narratology suggests narrative tools and basic theoretical narratological assumptions which give access for the interpreters to realize the nature of a narrative text.

Narrativity is a key concept in one's ability to remember and then reproduce his life experience. People tend to tell about their life in the form of stories with a set of participants, definite sequence of events, time and space measures. Narrativity is a core pattern for cognition and

${ }^{14}$ Shavit Z. Poetics of Children's literature. Athens and London : The University of Georgia Press, 1986. P. 42.

${ }^{15}$ Zipes J. Why fairy tales stick. The evolution and relevance of a genre. Lew York \& London: Routledge Tailor Francis group, 2006. 332 p.

16 Herman L., Vervaeck B. Handbook of narrative analysis. Lincoln and London: University of Nebraska Press, 2001. 232 p. 
comprehension one's life experience ${ }^{17}$. Roland Barth states: “...narrative is present in every age, in every place, in every society; it begins with the very history of mankind and there nowhere is nor has been a people without narrative... narrative is international, transhistorical, transcultural: it is simply there, like life itself" ${ }^{, 18}$. To create a narrative means to create a story world, by choosing the events, their sequence, different details, participants, point of view. Narrative as if invents an alternative image of what happened, will happen in future or just exists in one's imagination. To create a narrative means to make events look the way the author wants them to be. The author as a real creator of the story and the narrator, as a text category who/what implements it in the text, present the story like they choose it to be. To narrate a story is to juggle, play with verbal and non-verbal tools in order to make them accomplish the task one has put on them.

Jan Simons in his article "Narrative, Games and Theory" writes about a tie between narratives and games. A scholar claims that narrative as addressed to a certain narratee (an ideal implied reader who can comprehend the story), presupposes rather passive role for the narratee and a potential reader, who will read the story. A game as a set of certain rules and participants requires active position of its players. They don't just watch the events, they take part in their development ${ }^{19}$. Game is a social activity typically regulated by a set of fixed rules. It is a logically interesting combination of both the set of rules or regulations and a chain of all particular developments ${ }^{20}$.

Given that, narratives and games have lots of similar features:

- Games and narratives do not belong to real life, but imitate it to some extent;

- Games and narratives create a different/alternative reality which cannot be comprehended (come into life) until a real human (participant or reader) get involved in it;

- Games and narratives have the effect of total absorption. Game is played and narrative is read as if something happening here and now. One

${ }^{17}$ Simons J. Narrative, Game, and Theory. The international journal of computer game research, 2007. Volume 7. Issue 1. Retrieved from: http://gamestudies.org/07010701/ articles/simons

${ }_{19}^{18}$ Barthes R. Image Music Text. Fontana Press. Harper Collins Publisher, 1977. P. 79

19 Simons J. Narrative, Game, and Theory. The international journal of computer game research, 2007. Volume 7. Issue 1. Retrieved from: http://gamestudies.org/07010701/ articles/simons

${ }^{20}$ Chrzanowska-Kluczewska, E. Language games: pro and against. TAiWPN Universitas Kraków: Universitas, 2004. P. 21. 
can get absolutely involved into the story of the narrative or the state of a game;

- Games and narratives bring the feeling of curiosity, excitement, tension and desire to read/play to the end;

- Games and narratives make those who participate in them/read them comprehend what is played or what is read the way it is created (by the writer or a game inventor). For games it means following its rules and for narrative it means realizing the events in the story from the point of view of its characters, who live the plot as their own destiny;

- Games and narratives have "as-if" framing, they deal with imaginative situations and characters (roles). As-if framing effect preserves the atmosphere of both real and imaginary worlds. The measure can be defined by the author or game players/readers.

According to Sternberg's definition, narrativity is the play of suspense/curiosity/surprise between represented and communicative time (in whatever combination, whatever medium, whatever manifest or latent form).' Sternberg's three 'master strategies' signify different forms of the tension between expectation and experience ${ }^{21}$.

The hypothesis of the research is based on such key assumptions:

The matrix, which underlies fairy narratives for children, is a gamemodel matrix. Game-type narrative construing enables the author to involve his potential readers into the narrative as if in the game. Being in the game means being involved, captured, engaged in it. Curiosity, brainteasers are the key narrative story building elements, which are hidden in the plot of a fairy narrative. Fairy narratives for children are construed in such a way, that definite narrative (chronotope, characters, events of the story) and narrational (composition structure, key-words in narrative episodes) triggers activate in a child's mind his/her knowledge about the game and make him/her immerse in the text.

\section{Quest-model of construing a fairy narrative}

It is hypothesized in the research that fairy narratives "Charlie and the Chocolate Factory" and "Charlie and the great glass elevator" are construed like quest-model narrative stories. Thesaurus and etymological dictionaries prove that "quest is a long and difficult search",22, to have a

\footnotetext{
${ }^{21}$ Narratology and Interpretation / ed. by J. Grethlein, A. Rengakos. Berlin \& New York: Walter de Gruyter, 2009. P. 156.

${ }^{22}$ Oxford Paperback Dictionary Thesaurus. (2001). N.Y.: Oxford University Press. P. 727
} 
quest means to search and to conquer something precious ${ }^{23}$. While reading the story child-readers get involved into the story as if they play a quest game with the main characters. There are definite triggers which activate in a child's mind his/her knowledge about the quest as a search for something.

Narrative triggers. The plot of the fairy narrative - the search of the golden ticket and then the search of the secrets of the chocolate factory. All characters of the fairy narrative, Charlie Bucket, Mr. Willy Wonka, Augustus Gloop, Mike Teavee, Veruca Salt, Violet Beauregarde, are participants of the quest. They compete and try to complete all the tasks of the quest. The main price for the winner - the best chocolate factory one has ever seen. All the adventures of the main characters happen at a Chocolate Factory of a mysterious Willy Wonka.

"Charlie and The great glass elevator" is the sequel of the narrative about Charlie's adventures. Charlie, Willy Wonka and all Charlie's family travel in a giant glass elevator and rocket through the sky. The elevator circles the earth, finds the Space hotel, a unique attraction, created be the government of the United States, meet Vermicious Knids and have lots of different adventures on their way to the Chocolate Factory.

Narrational triggers. We assume, that all fairy narratives embrace various narrative episodes as autosemantic text fragments. Narrative episode represents one event of a character's life (its beginning and evolution) that happens within some time and space measures (chronotope). Such episodes are connected by different cognitive operations: extension, skewering, collision etc. A sequence (linear or nonlinear) of narrative episodes comprise the whole narrative as a story. Key narrative episodes, which refer to exposition, rising action, climax and final composition blocks, have a narrational triggers, i.e. lexical units with the semantics of search:

\section{Task of the Quest:}

I- to visit my factory this year. These lucky five will be shown around personally by me, and they will be allowed to see all the secrets and the magic of my factory. Then, at the end of the tour, as a special present, all of them will be given enough chocolates and sweets to last them for the rest of their lives! So watch out for the Golden Tickets! Five Golden Tickets have been printed on golden paper, and these five Golden Tickets have been hidden underneath the ordinary wrapping paper of five ordinary bars of chocolate. These five chocolate bars may be anywhere - in any

23 A Short Etymological Dictionary of Modern English. (1996). L.; N.Y.: Routledge. P. 2677. 
shop in any street in any town in a, Willy Wonka, have decided to allow five children - just five, mind you, and no more ny country in the worldupon any counter where Wonka's Sweets are sold. And the five lucky finders of these five Golden Tickets are the only ones who will be allowed to visit my factory and see what it's like now inside! Good luck to you all, and happy hunting! (Signed Willy Wonka.) ${ }^{24}$

He's brilliant!' cried Grandpa Joe. 'He's a magician! Just imagine what will happen now! The whole world will be searching for those Golden Tickets! Everyone will be buying Wonka's chocolate bars in the hope of finding one! He'll sell more than ever before! Oh, how exciting it would be to find one! 25

Rising action: The very next day, the first Golden Ticket was found. The finder was a boy called Augustus Gloop ${ }^{26}$

And now the whole country, indeed, the whole world, seemed suddenly to be caught up in a mad chocolate-buying spree, everybody searching frantically for those precious remaining tickets ${ }^{27}$

vowed I would keep up the search 28

And now, you and I are going to have one more fling at finding that last ticket ${ }^{29}$

Of course I'm sure!' spluttered the old man excitedly. 'Don't stand there arguing! I'm as keen as you are to find that ticket! Here - take the money and run down the street to the nearest shop and buy the first Wonka bar you see and bring it straight back to me, and we'll open it together

How did he manage to find it, I'd like to know?' a large boy shouted angrily. 'Twenty bars a day I've been buying for weeks and weeks!',30

Greetings to you, the lucky finder of this Golden Ticket, from $\mathrm{Mr}$ Willy Wonka! I shake you warmly by the hand! Tremendous things are in store for you! ${ }^{31}$

\section{Final. The winner:}

Mr Wonka suddenly exploded with excitement. 'But my dear boy,' he cried out, 'that means you've won!' (addressing to Charlie)... 'You see, my dear boy, I have decided to make you a present of the whole place. As soon as you are old enough to run it, the entire factory will become yours. ${ }^{32}$

\footnotetext{
${ }^{24}$ Dahl, R. Charlie and the Chocolate Factory. London: Puffin, 2013. P. 23.

${ }^{25}$ Dahl, R. Charlie and the Chocolate Factory. London: Puffin, 2013. P. 17.

${ }^{26}$ Dahl, R. Charlie and the Chocolate Factory. London: Puffin, 2013. P. 19

${ }^{27}$ Dahl, R. Charlie and the Chocolate Factory. London: Puffin, 2013. P. 19

${ }^{28}$ Dahl, R. Charlie and the Chocolate Factory. London: Puffin, 2013. P. 21.

${ }^{29}$ Dahl, R. Charlie and the Chocolate Factory. London: Puffin, 2013. P. 28.

${ }^{30}$ Dahl, R. Charlie and the Chocolate Factory. London: Puffin, 2013. P. 36.

${ }^{31}$ Dahl, R. Charlie and the Chocolate Factory. London: Puffin, 2013. P. 39

${ }^{32}$ Dahl, R. Charlie and the Chocolate Factory. London: Puffin, 2013. P. 115.
} 
Four quest participants, who start the quest at the beginning of the fairy narrative, fail to overcome their vanity and greed, as a result they stop to compete. Charlie Bucket, a kind-hearted and compassionate boy, becomes the winner.
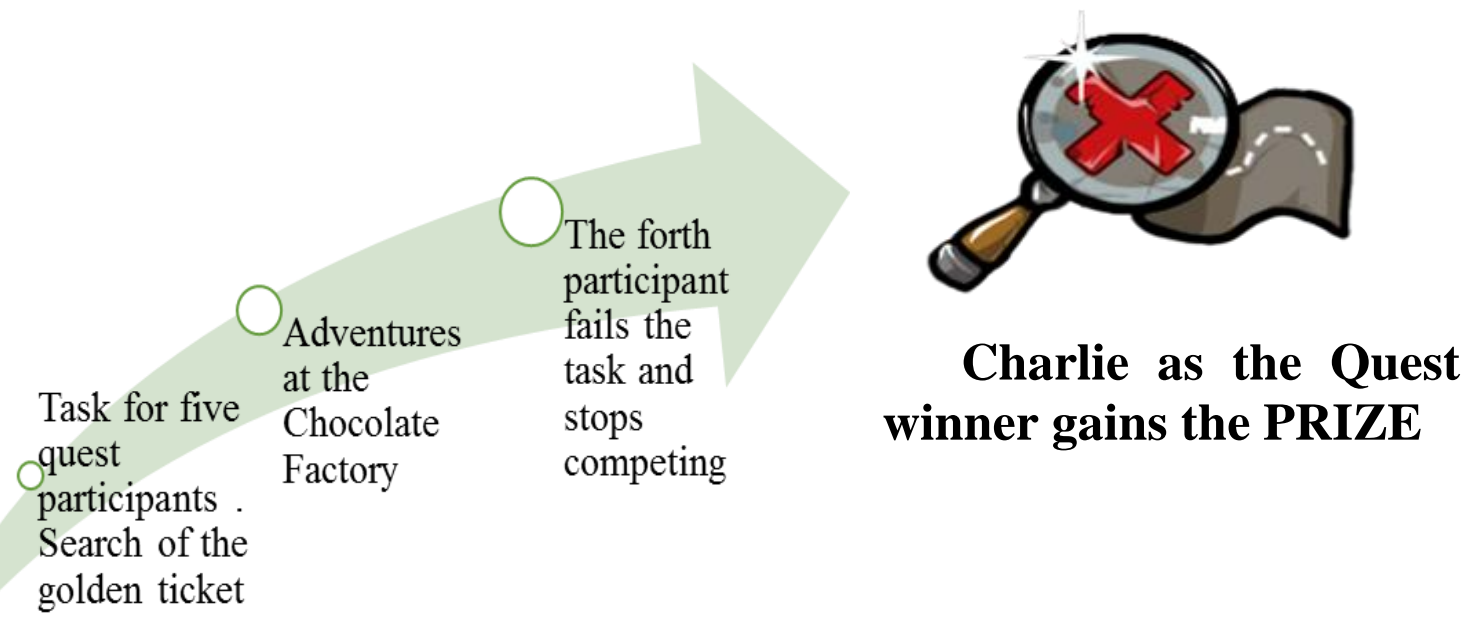

\section{Fig. 1. Quest-model of narration (search and find for being bright)}

The quest-modelled narrative as a story about the search of Chocolate factory's secrets and the quest in a great glass elevator are construed with the help of various narrative means and stylistic devices, which furnish fairy text world with child-oriented expressive means and stylistic devices.

Narrative means, verbally and non-verbally expressed, enable the author to construct the fairy story. In the next part we are going to explain the nature of child-oriented stylistic means and give examples of verbal and visual means of fairy narrative construing.

\section{Furnishing fairy text worlds with child-oriented metaphors}

As it is known, text world is the sets of scenarios and type of reality that the text is about. The text worlds of fiction and literature are cognitive and cultural constructs that are imagined by speakers or writers in text production and by listeners or readers in text comprehension. The text world of fiction and literature are rich, dynamic, "furnished" worlds: they are inhabited by concrete individuals who are endowed with specific properties and involved in specific events unfolding in specific settings 
$(\text { E.Semino })^{33}$. The nature of text worlds results from the fact that texts can only explicitly provide a limited amount of information about the worlds they project. A child-reader furnishes the world of a fairy narrative by combining elements from his/her knowledge and experience of the world of the fairy tale with the knowledge of the real world he/she lives in. Differences in the nature and amount of the knowledge available to readers will result in differences in their interpretation and appreciation of the text.

One of the most important things is that it may happen that a childreader requires additional knowledge and experience to construct a text word of a fairy tale in his mind. It happens if a child-reader meets in the text some objects, notions, things he cannot reconstruct from his encyclopedia. Thus, the narrator of a fairy narrative, which is addressed to a child-reader must construct fairy text world in a special way so to make it interesting, clear and intelligible for the addressee.

It is claimed that expressive means, stylistic devices, images, plot and composition of such texts have a child-oriented tendency. It proves the realization of key narrative strategy of the author - the strategy of simplification. The author chooses the narrative strategy and the model of narration according to his intention - to educate, advertise, motivate or amuse a child.

In fairy narratives for children the harmony of expressive means, stylistic devices, lexical, syntactic, composition and plot text forming units have a child-oriented tendency. Child-oriented metaphors and similes have in their background play/game, sensitive, gastronomic images which a child can see, feel and taste in his/her everyday life. Such storytelling units create poetics of simplicity in literary texts for children. Gastronomic/sensory images make a child reader immerse in the text and realize unknown for him/her objects with the help of well-known things that already exist in a child's experience.

Conceptual metaphor is viewed as key issue in the language analysis from the perspective of cognitive linguistics. Conceptual metaphor presupposes projection between two mental representations (source and target conceptual domains).

The mechanisms that underlie gastronomic metaphors in fairy narratives involve relationships between source and target conceptual domains (definite characteristics/elements of the source domain are projected into characteristics of the target domain).

\footnotetext{
${ }^{33}$ Semino E. Text worlds. Cognitive poetics: Goals, Gains and Gaps. Berlin. New York : Mouton de Gruyter, 2009. P. 33-73
} 
The concept of the Great Chain of Being, suggested by Lakoff and Turner $(1989)^{34}$, explains the mechanisms that underlie conceptual mapping of two conceptual domains. The Great Chain of Being suggests hierarchy : "The Great Chain of Being is a cultural model that concerns kinds of beings and their properties and places them on a vertical scale with \"higher" beings and properties above \"lower \" beings and properties $" 35$.

The Great chain of Being is represented as a scale:

- HUMAN

- ANIMAL

- PLANT

- INANIMATE OBJECT

Humans are tho2ugh higher-order beings than animals, animals are higher-order beings than plants and so on. Each of the levels has sublevels. i.e. - dogs are higher than insects and trees are higher than algae.

- Each unit in this scale of being embodies a scale of properties generic-level parameters, interior states, cognitive abilities (for humans these are mental, moral, aesthetic parameters), instincts (for animals), for substance - a part-whole functional structure, properties:

- HUMANS: Higher-order attributes and behavior (thought, character);

- ANIMAL: Instinctual attributes and behavior;

- PLANTS: Biological attributes and behavior;

- COMPLEX OBJECTS: Structural attributes and functional behavior;

- NATURAL PHYSICAL THINGS: Natural physical attributes and natural physical behavior.

Child-oriented metaphors and similes aim at furnishing a fairy-text world of a fairy tale with the units that are understandable for a childreader. Most unknown objects, living beings, emotional states of characters, their feelings are represented by the narrator by means of childoriented metaphors, similies that have gastronomic nature - all potentially unknown things for a child are understood by means of projecting physical properties (shape, size, temperature, structure, density) of well-known items of food to the properties of unknown or not easily comprehended objects.

The main characters of a fairy narrative "Charlie and the Chocolate factory" are Charlie Bucket and four children-participants of a quest at a

\footnotetext{
${ }^{34}$ Lakoff, G., Turner, M. More than cool reason: a field guide to poetic metaphor . The University of Chicago Press. Chicago and London, 1989. 237 p.

${ }^{35}$ Lakoff, G., Turner, M. More than cool reason: a field guide to poetic metaphor . The University of Chicago Press. Chicago and London, 1989. 237 p.
} 
Chocolate factory. In a sequel fairy narrative "Charlie and the Great Glass Elevator" readers can meet Charlie Bucket and his family members as the main characters of the narrative. All Roald Dahl's fairy narratives are accompanied by original illustrations by Quentin Blake. Narrative episodes are construed with the help of verbal and nonverbal means which create a complex multimodal text i.e. several semiotic codes (verbal text and visual text) are used for decoding and encoding the information. Visual text is the vehicle that can probe the ambiguities of vision ${ }^{36}$. Child-readers read the story (some episode) told by the words and pictures, it activates their crossmodal seeing. It becomes a powerful sense-making resource to integrate the modes of sensory experience. Book illustrations have the tendency for narrativization $^{37}$. Children can easily recognize the narrative story and remember the events when seeing its illustration either with main characters or some special artifact. Fairy narratives about Charlie begin with a visual narrative episode - character's appearance, accompanied by some verbal comments with their names. These visual episodes have a caricature/cartoon nature, as they represent main characters both ironically and funny (see fig. 2).

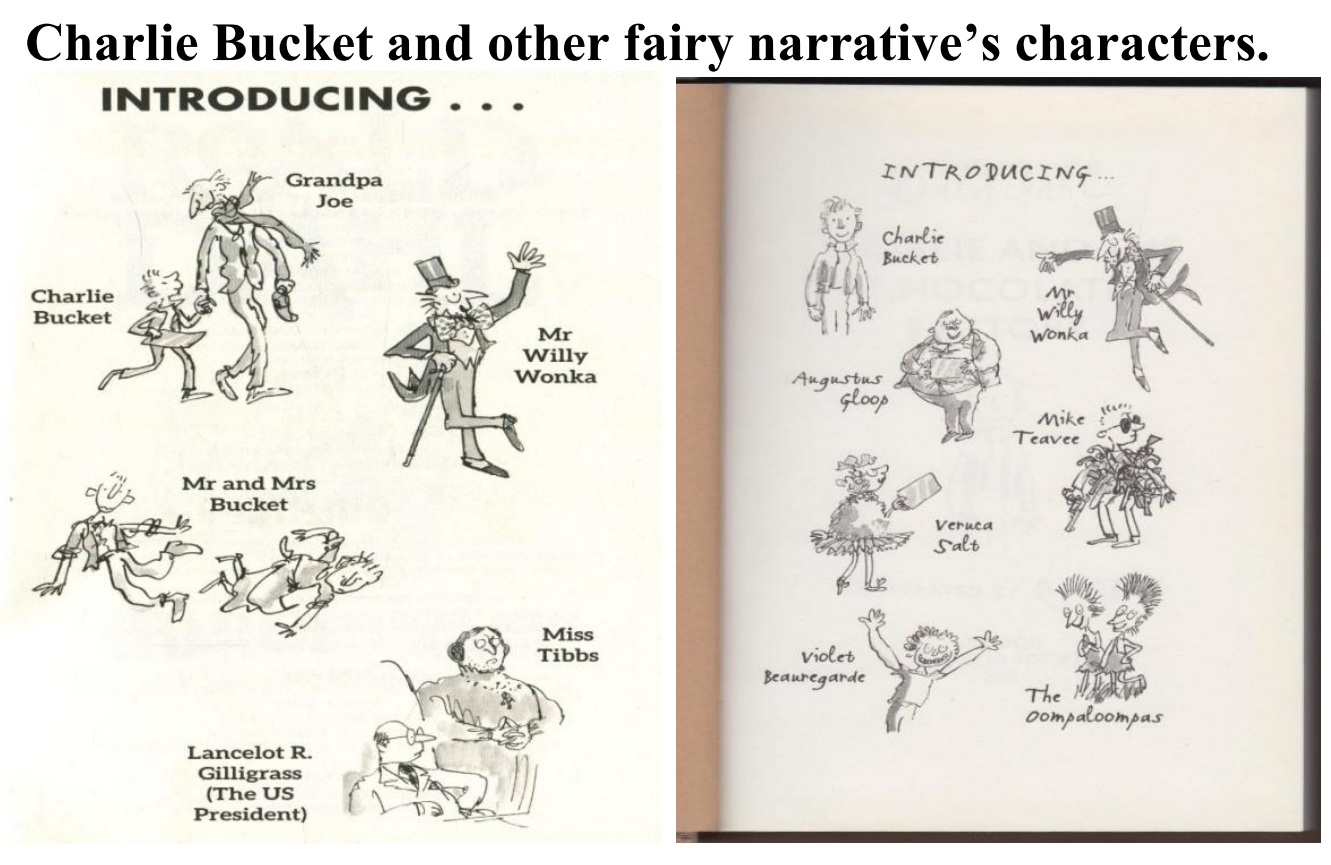

\section{Fig. 2. Visual representation of the main characters of R. Dahl's fairy narratives}

\footnotetext{
${ }^{36}$ Arizpe E. Styles M. Children reading picture books: interpreting visual texts. London \& New York: Routledge, 2016. P. 16.

${ }^{37}$ Toolan M. Seeing as, Hearing as, Reading as: Metaphoricity and Narrativity in Art, Music, and Poetry. Book of abstracts 2018 IALS Simposium: Text. Image. Music. 2018. P. 4-5.
} 
Charlie Bucket symbolizes modesty and honesty. He is sincere, kind and compassionate person. Though, four other quest-participants personify simulacrums of modern society (Bodriyar) - greed and gluttony (Augustus Gloop), parent's permissiveness (Veruca Salt), uncontrolled TV watching (Mike Teavee), vanity (Violet).

The narrator as if a "hidden adult" the point of view a didactic adult, who criticizes pseudo values of the characters and supports honesty of the main hero Charlie. The "hidden adult" who exists inside the text, describes the appearance of Augustus Gloop, the boy who adores eating and who is obviously obese, by means of gastronomic metaphors: the picture showed a nine-year-old boy who was so enormously fat he looked as though he had been blown up with a powerful pump. Great flabby folds of fat bulged out from every part of his body, and his face was like a monstrous ball of dough with two small greedy curranty eyes peering out upon the world ${ }^{39}$.

The combination of two lexical units - monstrous and dough create the image of ugly and shapeless body, as dough, it is sticky and soft but awfully looking. A child reader can imagine a fat Augustus whose great desire to eating too much has led him to such monstrous appearance. Such gastronomic simile (was like a monstrous ball of dough with two small greedy currant eyes) enables the narrator to create a desired perlocutionary effect on a child-reader - to demonstrate awful consequences of overeating. The conceptual metaphor that underlies: HUMAN'S CHARACTERISTICS ARE FOOD ITEM'S PROPERTIES

(Fat face $=$ ball of dough; appearance of a child - the view of a ball of dough)

For example, the emotional state of fear is represented with gastronomic simile: “We'll be scrambled like eggs!" said Grandma Georgina $^{40}$.

When Grandma Josephine feels the trouble they are in is too dangerous, she explains her emotions : "We're in a hot enough stew already" as if it is a boiling hot stew. The President of the USA is the fairy narrative is depicted as absolutely childish person who is afraid of aliens and unknown space ships: "We'll be mashed like potatoes" characters, either grown ups and children, in the fairy text worlds of Roald

\footnotetext{
${ }^{38}$ Nodelman P. The hidden adult. Defining children's literature. Baltimore: John Hopkins University Press, 2008. 390 p.

${ }^{39}$ Dahl, R. Charlie and the Chocolate Factory. London: Puffin, 2013. P.

${ }^{40}$ Dahl R. Charlie and the great glass elevator. London: Puffin, 2013. P. 5.

${ }^{41}$ Dahl R. Charlie and the great glass elevator. London: Puffin, 2013. P. 48.
} 
Dah's fairy narratives speak the same language and explain their feelings and emotions like children: Turbulence is realized by the fairy narrative characters as the feeling of fish in a tank: "...They are all floating about like fish in a tank!" ${ }^{42}$.

In the fairy narrative "Charlie and the great glass elevator", all the heroes appear in a magic glass elevator that flies high in the sky. Grandma Josephine looks down on earth and the narrator comments: "Through the glass floor she saw the entire continent of North America nearly two hundred miles below and looking no bigger than a bar of chocolate") ${ }^{43}$. The whole continent (its size) is compared with the bar of chocolate $=$ THE SIZE OF THE NATURAL PHYSICAL THING (CONTINET) IS THE SIZE OF A GASTRONOMIC ITEM (BAR OF CHOCOLATE).

An unusual look of Space Hotel, which flies in the sky, is represented to a child-reader via gastronomic epithet: "...its first Space Hotel, a gigantic sausage-shaped capsule..." ${ }^{44}$. A space hotel is a magic object the knowledge of which does not exist in a child-reader's experience. Such epithet enables the reader to imagine its physical configuration and at the same time makes the hotel funny and curious. A space hotel is not something ugly and strange, it is nothing more than a big flying sausage. Visual narrative episode (Fig. 3) duplicates the verbal information. Such narration simplifies a child-reader's comprehension of new objects.

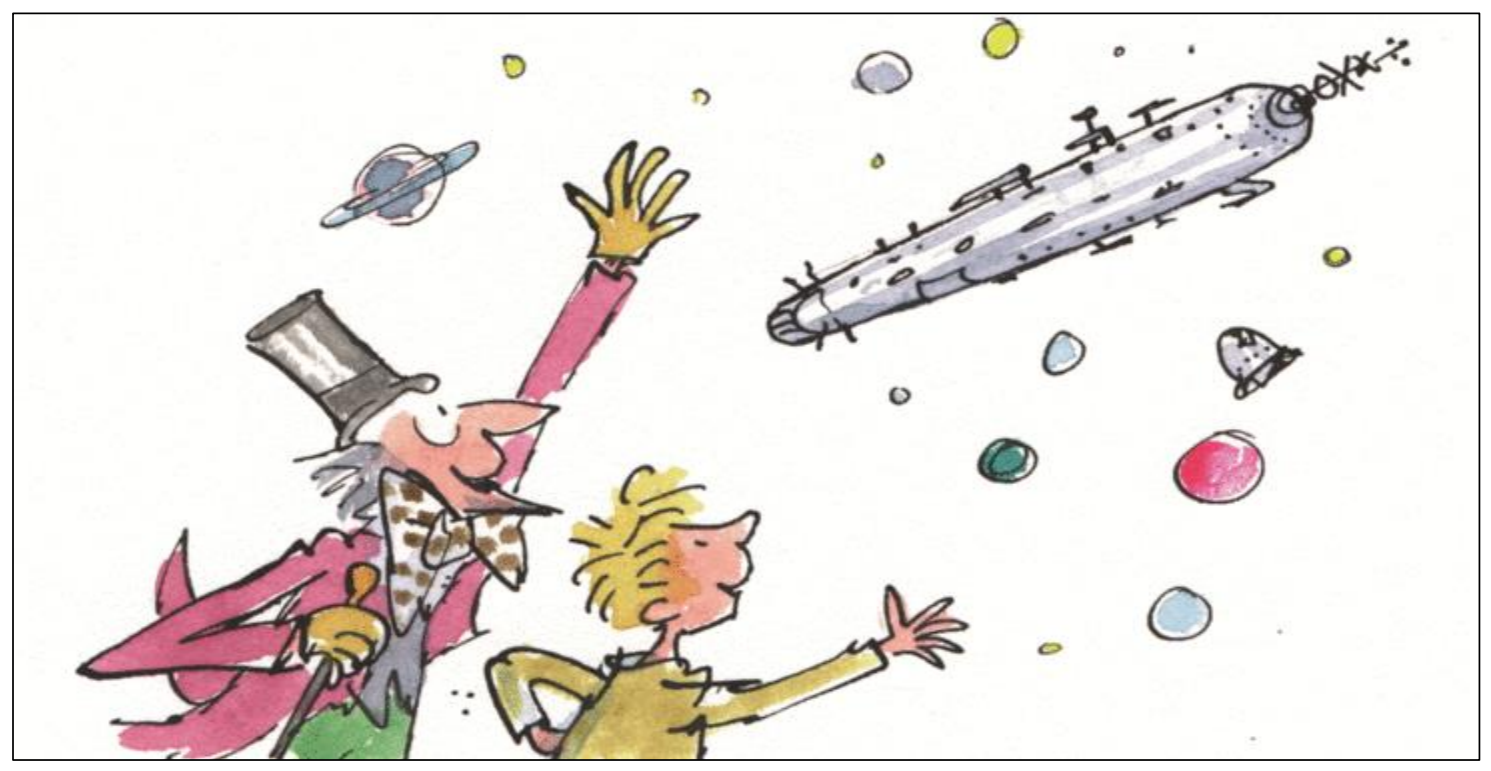

Fig. 3. Sausage-shaped spaceship

\footnotetext{
${ }^{42}$ Dahl R. Charlie and the great glass elevator. London: Puffin, 2013. P. 9

${ }^{43}$ Dahl R. Charlie and the great glass elevator. London: Puffin, 2013. P. 8.

${ }^{44}$ Dahl R. Charlie and the great glass elevator. London: Puffin, 2013. P. 12.
} 
The alien in the fairy narrative has such appearance: "It was as tall as a big boy and wider than the fattest man. The greenish-brown skin had a shiny wettish apeearance and there were wrinkles in it. About threequarters of the way up, in the widest part, there were two large round eyes as big as tea-cups...the entire egg-shaped body was itself moving... "45. Such verbal description of an alien's appearance is rather delailed. Visual picture just duplicates it (see Fig. 4). Narrative means of story construing verbal and visual, enable a child-reader to have a holographic picture of a space alien. LIVING BEING APPEARANCE (SHAPE AND SIZE) IS THE APPEARANCE OF OBJECTS (FOOD ITEM (EGG) AND DISHES (TEA-CUPS)).

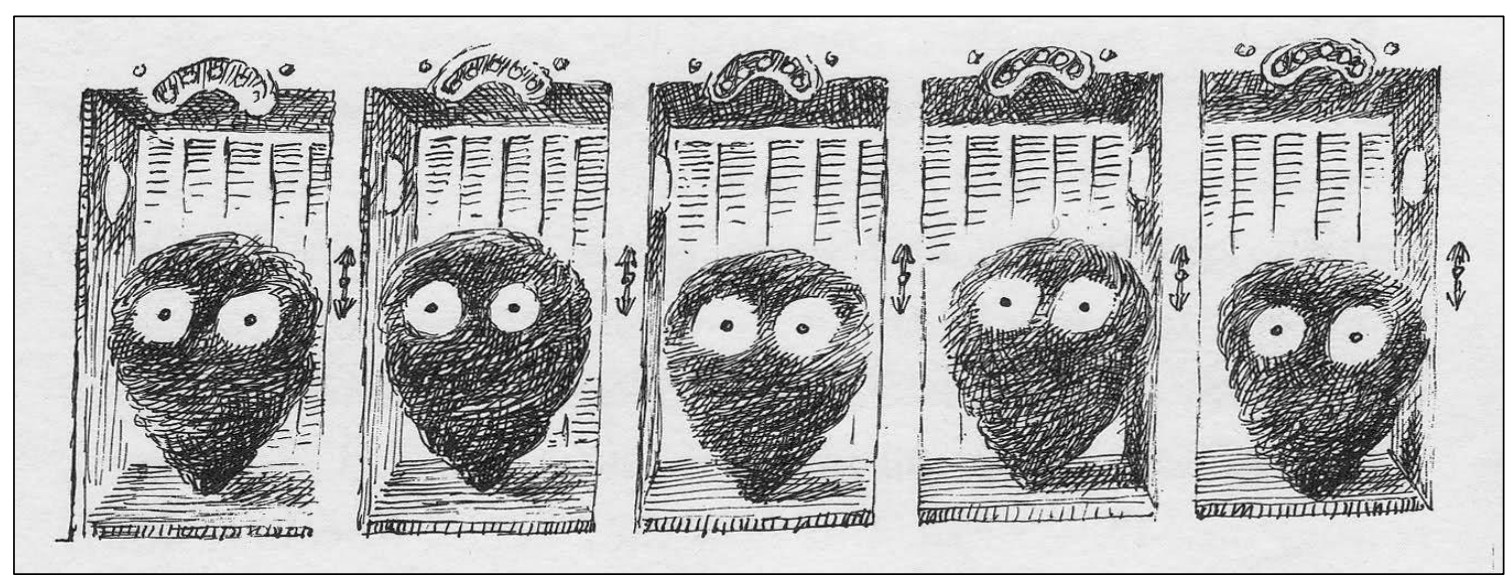

Fig. 4. Aliens: Vermicious Knids

The distance that is covered in a fairy narrative is the distance between daily meals: "...travelling a million miles between lunch and supper, and then another million before breakfast the next day. How else could they travel between the planet Vermes and other stars?". A strange noise becomes familiar when compared with the sound of the frying bacon: "Inside the Elevator they could actually hear it sizzling. It made a noise like bacon frying". Such fairy text world furnishing creates a special narrative for child-readers. Child-oriented metaphors make unknown and odd objects funny and .

\section{CONCLUSIONS}

The main factor, taken into account while creating literary texts for children (fairy narratives) is the factor of addressee. The addressee of fairy narratives is a child and his/her linguistic competence, life experience,

\footnotetext{
${ }^{45}$ Dahl R. Charlie and the great glass elevator. London: Puffin, 2013. P. 56-57.
} 
emotional and psychological maturity require a special way of storytelling to achieve a necessary fiction communication. Narratives, construed like games, make children not just readers, but participants of the narrative story. Such narrative modelling makes them immerse in the text. Narrative and narrational triggers (quest-story and key narrative triggers in narrative episodes) activate in children's mind their knowledge about the quest game and all the emotions they feel when playing.

Child-oriented metaphors and similes enable to furnish a fairy text world with original images and explain to a child-reader unknown for him/her things by means of gastronomic and sensory images that exist in child-reader's experience. The realization of the narrative strategy of simplification enables to achieve a desired perlocutionary effect and to realize author's intention to make a child believe in magic, magic transformation, to teach a child what is good and what is evil.

\section{SUMMARY}

The matrix, which underlies fairy narratives for children, is a gamemodel matrix. Game-type narrative construing enables the author to involve his potential readers into the narrative as if in the game. Being in the game means being involved, captured, engaged in it. Curiosity, brainteasers are the key narrative story building elements, which are hidden in the plot of a fairy narrative. Fairy narratives for children are construed in such a way, that definite narrative (chronotope, characters, events of the story) and narrational (composition structure, key-words in narrative episodes) triggers activate in a child's mind his/her knowledge about the game and make him/her immerse in the text. Fairy narratives "Charlie and the Chocolate Factory" and "Charlie and the great glass elevator" are construed like quest-model narrative stories. Three main narrative features: Events (search/quest) \& Evolution (competition and the winner), Temporality (events develop around the quest and finish when the hero wins it), Characters (quest-participants) and setting (magic chocolate factory and glass elevator) are construed like a quest-game. Such narratives enable to make child readers get engaged into the plot and become active participants of the events.

Fairy text world of fairy narratives are furnished with child-oriented metaphors and similes. Most unknown objects, living beings, emotional states of characters, their feelings are represented by the narrator by means of child-oriented metaphors, similies that have gastronomic nature - all potentially unknown things for a child are understood by means of projecting physical properties (shape, size, temperature, structure, density) 
of well-known items of food to the properties of unknown or not easily comprehended objects.

The main strategy of narration of fairy narratives for children is the strategy of simplification. Verbal and visual means of narration provide child-readers with detailed verbal description and visual representation of key notions of the fairy narrative. As a rule, visual narrative episodes duplicate verbal description, so than child-readers could comprehend a holographic picture.

\section{REFERENCES:} $944 \mathrm{c}$

1. Женетт Жерар Фигуры . М.: изд-во им. Сабашниковых, 1998.

2. Пропп В. Морфология сказки. Ленинград: «Academia», 1928. $152 \mathrm{c}$.

3. Шмид В. Нарратология. М. : Языки славянской культуры, 2003. 312c.

4. A Short Etymological Dictionary of Modern English. (1996). L.; N.Y.: Routledge. P. 2677.

5. Arizpe E. Styles M. Children reading picture books: interpreting visual texts. London \& New York: Routledge, 2016. 214 p.

6. Bal M. Narratology. Introduction to the theory of narrative. Toronto. Buffalo. London : University of Toronto Press, 2017. 205 p.;

7. Barthes R. Image Music Text. Fontana Press. Harper Collins Publisher, 1977. P. 79

8. Chatman S. Story and discourse. Narrative structure in fiction and film. Ithaca and London: Cornell University Press, 1980. 277 p.;

9. Chrzanowska-Kluczewska, E. Language games: pro and against. TAiWPN Universitas Kraków: Universitas, 2004. P. 21.

10. Fludernik M. An introduction to narratology. London and New York: Rouledge. Taylor and Francis group, 2002.190 p.

11. Hahn D. The Oxford companion to Children's literature. Oxford University press, 2017. P. 123-124.

12. Herman L., Vervaeck B. Handbook of narrative analysis. Lincoln and London: University of Nebraska Press, 2001. 232 p.

13. Hunt P. Understanding Children's literature. London and New York : Routledge Taylor and Francis Group, 2005. 225 p.

14. J. Gavins Text world theory. An introduction. Edinburgh University Press, 2007. 103 p.

15. Lakoff, G., Turner, M. More than cool reason: a field guide to poetic metaphor . The University of Chicago Press. Chicago and London, 1989. $237 \mathrm{p}$.

16. Margolin, U. Narrator. Handbook of narratology. Berlin / New York : Walter de Gruyter, 2009. P. $351-365$ 
17. Narratology and Interpretation / ed. by J. Grethlein, A. Rengakos. Berlin \& New York: Walter de Gruyter, 2009. P. 156.

18. Nikolajeva M. Children's literature comes of age. London and New York: Rouledge Taylor \& Frances Group, 2016. 225 p.

19. Nodelman P. The hidden adult. Defining children's literature. Baltimore: John Hopkins University Press, 2008. 390 p.

20. Oxford Paperback Dictionary Thesaurus. (2001). N.Y.: Oxford University Press. P. 727.

21. Ryan Marie-Laure Possible Worlds, Artificial Intelligence and Narrative Theory. Bloomington: Indiana University Press, 1991. 304 p.;

22. Semino E. Text worlds. Cognitive poetics: Goals, Gains and Gaps. Berlin. New York : Mouton de Gruyter, 2009. P. 33-73;

23. Shavit Z. Poetics of Children's literature. Athens and London : The University of Georgia Press, 1986. 193 p.

24. Shklovsky V. Theory of Prose. Dalkey archives press, 1991. 240 p.

25. Simons J. Narrative, Game, and Theory. The international journal of computer game research, 2007. Volume 7. Issue 1. Retrieved from: http://gamestudies.org/07010701/articles/simons

26. Toolan M. Seeing as, Hearing as, Reading as: Metaphoricity and Narrativity in Art, Music, and Poetry. Book of abstracts 2018 IALS Simposium: Text. Image. Music. 2018. P. 4-5.

27. Tsur R. Metaphor and figure-ground relationship: comparisons from poetry, music, and the visual arts. Cognitive poetics: goals, gains and gaps. Berlin. New York : Mouton de Gruyter, 2009. P. 237-279.

28. Zipes J. Why fairy tales stick. The evolution and relevance of a genre. Lew York \& London: Routledge Tailor Francis group, 2006. 332 p. 29.

\section{SOURCES:}

Dahl, R. Charlie and the Chocolate Factory. London: Puffin, 2013. 180 p. Dahl R. Charlie and the great glass elevator. London: Puffin, 2013. 182 p.

Information about the author: Tsapiv A. O.,

Candidate of Philological Sciences, Associate Professor at the Department of Translation Studies and Applied Linguistics, Postdoctoral Student at the Department of the English Language and Methodology of its Teaching, Kherson State University 27, Universytetska str., Kherson, 73000, Ukraine 